\title{
Dividing Competences: Germany's Vision(s) for Europe's Federal Future
}

\author{
Eiko R. Thielemann
}

Department of Government/European Institute, London School of Economics and Political Science, Houghton Street, London WC2A 2AE, UK. E-mail: e.thielemann@1se.ac.uk

Germany's preferences regarding the kind of federal Europe it wants have been characterized by both continuity and change. While its preferences regarding (horizontal) institutional developments at the European level have remained relatively stable, its preferences on the vertical distribution of power in Europe have changed. Perhaps the most important shift has been the recent German push for a European federation modelled on a dual (competitive) federalist system in which competencies are divided vertically by policy sector, rather than on a cooperative federalist model in which decision-making power is shared across levels of government. This paper argues that this change had little to do with strategic considerations by the Federal Government about how Germany should position itself in Europe after unification. Instead it can largely be explained by the growing dissatisfaction with the performance of Germany's cooperative federalist model, in particular on the part of the German Länder who are seeking new ways to overcome centralizing tendencies inherent in both the German and the EU system of governance. By analysing German contributions to the EU's constitutional debate, the paper assesses the relative importance of norms, interests and ideas in shaping German preferences on the type of European federation it wants.

Comparative European Politics (2004) 2, 358-374. doi:10.1057/palgrave.cep.6110039

Keywords: Germany; federalism; European constitution; preferences; competences

\section{Introduction}

Are Foreign Minister Fischer's provocative Humboldt speech on the 'finality' of Europe or Chancellor's Schröder's recent insistence on double majority voting, a sign of a new assertiveness in Germany's European policy? And does this mean that Germany is straying away from the commitment and selfrestraint it has traditionally shown in European integration matters? This article argues that, though there is substantial continuity in Germany's preferences towards the EU and its institutions, there have also been significant changes, as expressed by German actors in the recent discussion on the future EU constitution. Perhaps the most important and surprising change has been Germany's push for a European federal model along the lines of a dual (competitive) system, in which competences are divided vertically by policy sector, rather than a German cooperative federal model in which competences 
and decision-making powers are shared across levels of government. This, as argued below, represents a significant shift in the kind of European federation Germany wants.

The contention of this article is that this change had little to do with strategic considerations on the part of the Federal Government about how Germany should position itself in Europe after unification. Instead, it can be explained as a result of an increasing dissatisfaction with the performance of Germany's federal model.

In particular the Länder support of the idea of 'competitive federalism' as a way of overcoming centralizing tendencies inherent in both the German and the EU system of governance. German calls for a clearer division of powers in Europe are, therefore, not so much a product of structural changes in Germany's external environment, but the result of interest calculations and learning on the part of the Länder, which operate in a domestic institutional framework that allows them significant influence over the position adopted by the Federal Government in EU negotiations.

The article is organized into three parts: the first offers an overview of German preferences on European integration and EU constitutional reform and analyses to what extent these have changed; the second section shows how Germany's preferences have shifted from advocacy of cooperative federalism to support for a more competitive federal model for Europe; and the third assesses the relative power of norms, interests and ideas in explaining stability and change of Germany's European preferences over time.

\section{German Preferences on European Integration and EU Constitutional Reform: Continuity and Change}

The German Federal elections in September 1998 did not only lead to a new red-green government, but also marked a generational change in Germany's political leadership, with Gerhard Schröder becoming the first Chancellor without personal experience of World War II to accede to the office. Some observers expected that the new German Government would rid itself of the self-imposed shackles in its European policy. However, evidence suggests that despite the end of the cold war, unification and the coming to power of the redgreen government, Germany's European preferences - Schröder's more nationalistic rhetoric notwithstanding ${ }^{1}$ - have remained pro-integrationist and in many aspects similar to those held by previous governments. Evidence of such continuity can be found when analysing Germany's approach to the German Council Presidency in 1999, the Nice negotiations, and the recent talks on the European Constitution. 


\section{The pre-Nice agenda}

The new red-green government emphasized the central importance of the EU in German politics in its coalition agreement of October 1998. In his first address as Chancellor, Schröder underlined his commitment to regular consultations with France and the United Kingdom, and underlined the commitment to the Franco-German relationship as one of the foundations of Germany's European policy. In his speech in front of the European Parliament that marked the start of the German Presidency, Foreign Minister, Joschka Fischer identified the four priorities of the German government as: budgetary negotiations; the creation of a European employment pact; institutional reform in view of Eastern enlargement; and the strengthening of the Common Foreign and Security Policy. He stressed, in addition, Germany's commitment to a European area of Freedom, Security and Justice, as well as the creation of a European Charter of Fundamental Rights. In the same speech, for the first time, he also called for a discussion on the 'finality' of European integration.

Its continued commitment to deepening and widening notwithstanding, the German government did attempt to portray a more confident approach towards the budgetary negotiations, which dominated the German 1999 Council presidency. At that time, Schröder declared that the times when EU compromises were reached because of Germany's willingness to pay for them had definitely come to an end (Der Spiegel, Nr.1, 1999). In the end, however, Germany's EU presidency did not achieve any significant improvement in Germany's net contribution to the EU budget. Fischer commented that the Berlin compromise on Agenda 2000 was possible only because Germany (yet again) decided not to fully insist on its declared national interest position (Fischer, 1999).

As the member states turned their attention to the institutional issues raised by the impending enlargement, Chancellor Schröder outlined the German objectives for the Nice negotiations in a speech to the German Parliament on 28 November 2000: more QMV, more co-decision and the rotation of Commissioners as the solution to the reform of the Commission. ${ }^{2}$ With regard to the question of voting in the Council, Schröder called for a solution that 'was more closely oriented to the realities', without making clear whether this implied a departure from the principle of Franco-German parity in the Council. The Nice Intergovernmental Conference (IGC) — or what the Frankfurter Allgemeine Zeitung (12 December 2000) called the 'summit of the carpet dealers' - was seen at least by some as a success for Germany as the German government had de facto achieved the end of the historical parity with France through its gains in terms of European Parliament seats. 'Without arrogance, and with great sensitivity for its partners/opponents, Berlin has de 
facto managed to rid itself from the chain of historical parity with France' commented La Repubblica (quoted in Müller-Brandeck-Bocquet, 2002, 183). However, the fact that Germany did not regard Nice as the last word on institutional reform was made clear when Germany insisted on the inclusion of a commitment - Declaration 23 - on 'The Future of the European Union' which, post-Nice, committed the EU to despite the resistance of France institutional reform process.

\section{The Nice 'left-overs'}

A further success was Germany's ability to secure inclusion of a number of its favoured themes in the wish list for discussion in the Declaration on the Future of the Union that one finds in a protocol attached to the Nice Treaty. This list includes the five major themes that the Constitutional Convention was intended to address: the status of the charter of fundamental rights, simplification, transparency, the role of national parliaments and the division of competences. The most important and controversial of these issues was arguably the last, relating to the question of the horizontal and vertical division of powers. Although there was a strong element of continuity in Germany's preferences on the horizontal division of powers - namely, the question of how powers should be divided between the various institutions at the European level - a significant preference shift with respect to the vertical division of responsibilities between the EU, the national and the regional level of government in Europe could be detected.

On the question of the horizontal division of competences, the principal German concern was to enhance the effectiveness of the EU institutions in view of enlargement for which Germany has been one of the principal advocates. The German government went along with the idea of a permanent president of the Council, which was pushed for by Chirac, Blair and Aznar. However, Germany insisted that the new President's role should not undermine the roles of the President of the Commission and that of the new European Minister for Foreign Affairs. Although the red-green government in its coalition agreement had stressed the importance it attaches to the strengthening of the executive role of a European Commission responsible to the European Parliament, ${ }^{3}$ it was not categorically opposed to a strengthening of the Council. Chancellor Schröder, in his joint letter with Tony Blair acknowledged that 'the role of leadership of the European Council will become increasingly important'. ${ }^{4}$ On this issue, Schröder had had to overcome the reservations of Fischer, who feared that the Commission could become further sidelined in the process of giving the Council more power (Frankfurter Allgemeine Zeitung, 16 January 2003, 3). ${ }^{5}$ Germany has long been an advocate of strengthening the European Parliament and the Schröder government followed in this tradition, promoting 
in particular the right of a future European Parliament to elect the Commission President. The German government also held that the EP should 'generally' be provided with the right of co-decision in those areas in which the Convention and the IGC moved from unanimity to qualified majority decision in the Council. ${ }^{6}$ On the question of future EU external actions, Germany called for qualified majority voting as a general rule for the Council and expressed its opposition to combining the role of the Council's High Representative for CFSP and that of the Commissioner responsible for Foreign Affairs (Dehousse et al., 2003, 15). ${ }^{7}$

Fischer's Humboldt speech on the finality of Europe of 12 May 2000 attracted widespread attention, not so much because it signified a shift in German preferences but rather because no leading member of a German government before him had dared to express these preferences with the same degree of clarity. However, little of his speech conflicted with the traditional (less overtly expressed) German preferences for Europe's institutional future. With regard to the institutional architecture of the 'European Federation', Fischer left open the question of the place of national governments in such a system. Both a US Senate model (with elected national representatives) and a Federal Council similar to Germany's federal system appeared compatible with the framework he outlined.

Fischer's suggestions were echoed by President Rau's 'call for a European constitution, ${ }^{8}$ in which he too outlined the framework of a decentralized federal model. Like Fischer he did not specify whether he preferred a Senate or a Federal Council model for the representation of the Member States. Moreover, in line with the view of the German government, Rau stressed that the Charter of Fundamental Rights should be a central part of any future European Constitution. With regard to the horizontal distribution of powers in a future European Federation, Chancellor Schröder himself voiced the opinion that the European Commission should be developed into a strong European executive. This executive, should be complemented by a powerful two-chamber legislature, one chamber of which would be developed out of the existing Council (Schröder, 2001). Thus, there is little in German preferences on the distribution of powers at the European level that suggests a fundamental break with Germany's traditional European preferences in these matters (see also Kreile, 2001, 251).

Of all the issues put onto the agenda in the Nice protocol, arguably the one most clearly bearing Germany's imprint was the call for a catalogue of competences or what later became a demand for a clearer vertical 'division of powers between different levels of government. Largely as a result of German pressure, Declaration 23 of the protocol on the future of the Union commits Member State governments to the goal of establishing a clearer delimitation of competences between the EU and the Member States in accordance with the 
principle of subsidiarity. The German government pushed for the inclusion of these provisions above all as a result of pressures from the Länder, which had regularly expressed their fears (shared by some in the Federal Government) about a creeping transfer or power to Brussels. In a meeting with the Chancellor on 16 December 1999, the minister presidents of the Länder declared their intention of blocking ratification of the Nice Treaty in the Bundesrat, unless they received guarantees that the Schröder government would push for a clearer division of competences in the EU's multi-level governance structures (Müller-Brandeck-Bocquet, 2002, 185). ${ }^{9}$ The Federal Government did take these issues on board and Fischer in a speech to the Belgian parliament in November 2000 made it clear that the post-Nice objective of the German government was 'to achieve a clear division of sovereignty as between 'Europe' and the national states [and] to define the responsibilities of the Union and those of the national (or regional) governments'. These statements were the German government's response to pressure from the Länder, led by the premiers of North-Rhine Westphalia and the Minister President of Bavaria (Clement and Stoiber respectively). In a speech at Humboldt University, Berlin on 12 February 2001, Clement argued for a clearer division of powers and for the selective re-nationalisation of policy responsibilities to the Member States or their regions - a demand that was shortly afterwards taken up by the German Chancellor. ${ }^{10}$ Schröder proved sympathetic to demands for the re-nationalization of selected policy areas, as this fitted his ambition to improve Germany's budgetary situation. He also argued for the 'return' of certain tasks from Europe if they can be dealt with more effectively in the Member States, notably, agricultural and regional policy.

In a meeting of Europe ministers of the 16 Länder in Berlin on 31 May 2001, the Länder discussed the post-Nice process and agreed a joint declaration on how they viewed their role in the discussion on the 'future of the Union'. ${ }^{11}$ This declaration was presented to the joint working group of the Federal Government and the German Länder on the EU's constitutional process. In their subsequent meeting in Goslar, ${ }^{12}$ the Länder produced a long list of policy areas, where they called for the existing division of competences to be reexamined. They stressed that any reform of the system of EU competences should be based on the principles of limited and specific power transfers to the EU (Prinzip der begrenzten Einzelermächtigung), subsidiarity, proportionality and respect of the national identity of the Member States. They also demanded the abolition of Article 308 and called for the Committee of the Regions and regions with legislative powers to have the right to bring judicial challenges in competence issues. On 8 November 2001, Stoiber contributed to the Humboldt 'Europe' series. He criticized the centralisating tendencies of European integration and what he called the 'creeping competence enhance- 
ment' of the EU. While arguing for increased European powers in some areas such as foreign policy, he made the case for leaving most other tasks to the Member States. The positions laid out by Clement and Stoiber were reflected in the Bundesrat decision of 20 December 2001, which outlined principles and criteria for the future distribution of competences in the EU. ${ }^{13}$ It was relayed to the Convention through Erwin Teufel, the Bundesrat's representative. ${ }^{14}$ Among the German representatives at the Convention, it was Teufel for whom the issue of vertical division of competences had the highest priority. $^{15}$

Some observers have contended that Germany's position on the vertical division of responsibilities represents a continuation of the established, and successful, German strategy of exporting German institutions to the EU (Kreile, 2001, 252). Former French Interior Minister, Jean-Pierre Chévènement, for example, said about Fischer's Humboldt speech: 'We see a German tendency to imagine for Europe a federal structure based on its own model. At the bottom of this, Germany is still dreaming of the German Holy Roman Empire. It has not yet healed from the historical accident of Nazism' (Wall Street Journal Europe, 24 May 2000). However, looking at the proposals more carefully, it is hard to dispute that the German call for a clearer division of powers represented a radical departure from Germany's model of cooperative federalism and from the line the German government and, in particular, the Länder had taken on these issues in the past.

\section{From cooperative to competitive federalism in Europe}

Observers have noted that over the last 10 years, there has been a shift in the Länders' preferences regarding the EU. They have moved from a 'let us in' to a 'keep Europe out' approach. ${ }^{16}$

The process of European integration has always had major implications for the division of powers within the German federal system. The logic of the European integration process requires the transfer of competences from the domestic to the EU level. In so doing, it has involved a shift in the balance of power between domestic actors. As a result, European integration has not only shifted hitherto domestic competences (both national and subnational) to Brussels, it also had strengthened the position of the German Federal government vis-à-vis the Länder. European integration has not only challenged the sovereignty of the German Federal government, it has also challenged the legal status of the Länder and their prerogatives as (subnational) constituent states. ${ }^{17}$ There is therefore a general tension between the dynamic nature of European integration and the constitutionally guaranteed sovereign independence of the German Länder as has repeatedly been pointed out by the 
representatives of the Länder. ${ }^{18}$ In order to address this challenge, the Länder sought to extend and strengthen the ways in which they can participate in the European policy-making process. They have pursued this strategy both at the domestic level - for example, by creating new institutions for inter-Land cooperation (see Gerster, 1993) and the European level (e.g. through their regional information offices and their insistence that Länder representatives can represent Germany in the Council). However, despite these successes, frustration among the Länder has persisted. In particular, their inability to resist what they perceive as undue Commission intrusion into areas of regional competence, especially in competition policy and state aid, has been a serious issue for the Länder ${ }^{19}$ and they have sought ways of challenging such interference (Hrbek, 2002).

Recognizing that their strategy of protecting regional competences through greater participation in European matters has only been partly successful, the German Länder began to demand a more clearcut division of competences, culminating in their call for a fully specified competence catalogue in the run up to the Constitutional Convention. This means that the preferences of the Länder regarding what kind of federal Europe they want have changed from being based on a cooperative federal Europe in which different levels of government take part in joint decision-making, to one based on a more dualist (or competitive) federal model, characterised by a clear vertical separation of competences between different levels of government. This shift was first evident in the run-up to the Maastricht IGC, when the German Länder pushed for a new article on subsidiarity in the Treaties (Article 3b TEU). The ambiguous definition of subsidiarity, though, has raised the question of "whether the subsidiarity principle is usable [...] as a justifiable basis for any appeal or whether it can ultimately, if at all, develop any restraining political effect' (Hrbek, 1999, 228). Before the Convention, therefore, the Länder went further and demanded a clearer delineation of competences or even a competence catalogue, the introduction of a subsidiarity watchdog that would make this principle justiciable, and the right of subnational authorities such as the Länder to refer cases to such an authority. This attempt more clearly to delineate, restrict and, if necessary, renationalize European competences in particular in areas such as agriculture, regional policy and subsidy control, reflects an approach that seeks to keep Europe out of certain policy areas. As noted above, the new emphasis on a more dualist federal model for Europe has attracted widespread support among the Länder, but it has also received some support from the Federal Government.

In explaining continuity and change in Germany's European preferences, the next section refers to the role of norms, interests and ideas in shaping national preferences. 


\section{Explaining German Preferences}

How to explain the formation of national preferences in relation to European integration in general and EU institutional reform more specifically? March and Olsen (1998, 7-10) distinguish between two logics that guide social actors: a logic of expected consequences (based on a rationalist framework) and a logic of appropriateness (based on sociological insights). By highlighting the interaction of norms, interests and institutions in processes of national preference formation, these two models further our understanding of Germany's European preferences.

\section{The role of norms and identity}

According to the logic of appropriateness, preference formation is guided by notions of identity and roles shaped by the institutional context in which actors operate (March and Olsen, 1984; Checkel, 2001). According to this logic, preferences are shaped by rules, practices and norms that are socially constructed, publicly known and anticipated. What actors want is often associated with what they consider 'appropriate' in a particular socio-cultural context. In this sociological framework, preference formation is a process in which notions of identity and appropriateness are sometimes more important to actors than a calculus of political costs and benefits (March and Olsen, 1989).

Many influential commentators on Germany have indeed emphasized the role of norms and identity in shaping German preferences on Europe. Emerging from the experiences of the Third Reich, the German Federal Republic became firmly committed to multilateralism in its foreign policy. It has been described as an 'economic giant' and a 'political pygmy' with its policy on Europe marked by a culture of Bescheidenheit (modesty) and Zurückhaltung (reserve). Anderson and Goodman write, for example, that: 'Over the course of forty years, West Germany's reliance on a web of international institutions to achieve its foreign policy goal, born of an instrumental choice among painfully few alternatives, became so complete as to cause these institutions to be embedded in the very definition of states interests and strategies. In effect, this is what we mean when we describe Germany's institutional commitments in the post-1989 period as reflexive; they have become ingrained, even assumed' (Anderson and Goodman, 1993, 60).

Some have therefore argued that German Europapolitik can be only be properly understood if one considers the socio-cultural determinants that have shaped the normative frames on which this policy has been based. According to Hyde-Price and Jeffery (2001, 692), Germany's European policy should not be viewed in terms of power-maximizing actors, but it should be analysed against 
the background of its deep normative foundations, 'predicated on distinctive socio-cognitive assumptions that structure German policy-makers' perceptions of their national foreign policy roles and their external environment' (HydePrice and Jeffery, 2001, 691; see also Katzenstein, 1997; Marcussen et al., 1999; Bulmer et al., 2000; Harnisch and Maull, 2001). How useful is such a normbased approach for shedding light on German preferences for the EU Constitution? Arguably, it can help to explain Germany's continued commitment to European solutions, its advocacy of the strengthening supranational institutions, but also its reluctance to take positions that would isolate it from its European partners.

Regarding the explanatory power of such normative approaches for Germany's preferences on the kind of federal Europe it wants, it is important to note that German experiences with federalism indeed go back a long time and rest on a legacy that predates the centralization policy of the Third Reich. Germans, acutely aware of dangers of radical centralization policies, have favoured a decentralized governance structure for Europe, which they regard as the most appropriate constitutional design for an ever closer Union. In this sense, German preferences for a European Federation appear to be influenced by a normative context in which German politicians find it difficult to imagine anything other than a decentralised, federal governance structure for the EU. Germany's preferences therefore appear, at least in part to be motivated by Germany's federal identity, yet such normative explanations seem unable to explain the apparent shift in German preferences from cooperative to more competitive forms of federalism. Indeed, almost by definition, German advocacy of a governance framework alien to Germany's cooperative federal tradition calls for explanations that go beyond sociological accounts of preference formation.

\section{The role of strategic interests}

In an alternative framework, preference formation can be seen as being driven by a logic of rational and strategic calculations that anticipate consequences. Actors decide what they want by evaluating expected consequences of holding particular actions, expecting other actors to do the same. In this model, actors arrive at their goals, interests and desires largely independently of their institutional context. Institutions affect 'only the strategic opportunities for achieving these objectives' (Immergut, 1997, 231). The logic of expected consequences is perhaps the most commonly accepted of frameworks for the interpretation of political life. Andrew Moravcsik operates within this logic when he develops his theory of national preference formation in the EU context. According to Moravcsik (1993, 481-483), national preference formation in the $\mathrm{EU}$ is a process by which governments aggregate and 
represent preferences articulated by different societal groups which are in competition with each other. The more powerful the particular domestic group, the more influence it is likely to have in shaping the government's position. Governments are expected to represent their country in a uniform manner as they act strategically in the international arena on the basis of goals that have been defined at the domestic level.

A number of influential commentators have explained Germany's European preferences with reference to what they see as evidence of materialist interest calculation and clearly identifiable national interests. For Ash, a major part of Germany's commitment to European integration was economic self-interest pure and simple. In his view, Germany has done extremely well out of the EC, with its growing trade surpluses far outweighing the cost of its large budget contribution (Ash, 1993, 389). Others have seen in Germany's advocacy of a federal model for Europe a strategic attempt to export domestic institutions to Europe, which in turn would make it easier for Germany to cope with the pressures of Europeanization - in other words, to facilitate its domestic adaptation to European requirements (Bulmer, 1997; Schmidt, 1997). Similarly, Moravcsik's account of German preferences from the European Coal and Steel Community to the Maastricht Treaty emphasizes the role of interests when trying to explain Germany's European preferences. Although economic interest calculations are primary in his account, he does concede that in the German case 'geo-political factors appear to have actually influenced core national preferences' (Moravcsik, 1998, 478).

During the recent constitutional debate about the division of competences, the role of national, and, in particular subnational, interest calculation, go a long way in explaining German preferences. On the question of the horizontal division of competences, Germany's preferences for a stronger European Parliament and a double majority in the Council are not completely new. However, since the reallocation of MEP seats at Nice, they can be regarded as not only addressing concerns of legitimacy, but also as furthering German interests. Regarding the vertical division of competences, Germany's call for a more US style, competitive federal, model for Europe appears to reflect strategic, cost-benefit considerations by the German Länder, and to some extent also on the part of the Federal Government. According to the 'logic of expected consequences', strategic preference calculations are shaped by the institutional context in which actors find themselves. Germany's cooperative federalism offers the German Länder unique opportunities to influence institutional developments at the European level, since they are able to use the Federal Council (Bundesrat) to assert veto power (or the threat of veto) over the ratification of international agreements, including changes to the $\mathrm{EC} /$ EU Treaties. 
All German Länder are concerned about the potential centralisating effects of European integration. However, it has been the larger and richer Länder that have pushed hardest for a clearer delineation of competences, believing that they have most to gain from pushing for a more independent role for the regions, which would allow them to compete successfully with other subnational entities in Europe. In addition to such cost-benefit calculations, there is also a party-political dimension to the calls of Länder for a clearer vertical division of competences in Europe. CDU/CSU-dominated Länder have been in the vanguard, with SPD-led North Rhine Westphalia the notable exception. Party politics has played an important role in the preference formation of key German actors - a dimension somewhat underplayed in Moravcsik's $(1997,1998)$ liberal intergovernmentalist account of preference formation.

\section{The role of ideas}

The importance of norms and strategic considerations notwithstanding, the shift in German preferences from cooperative to competitive federalism can only be understood against the background of the experience of the Länder with the centralizing tendencies of Germany's cooperative federalism (Hesse, 1962; Abromeit, 1992) and the widespread dissatisfaction with Germany's apparent inability to overcome the joint decision traps (Scharpf, 1988) that characterize Germany's federal system. For many, Germany's tradition of joint decision making and multiple veto-players has stifled long-needed reform to halt the continuing erosion of Germany's international competitiveness, which has meant that among OECD countries, in terms of average GDP and per capita growth, only Japan performed worse than Germany during the period 1990-2000. Wiesenthal (2003) summarizes what many now regard as the cooperative federalist rootcauses for the German 'performance crisis', which has led to widespread support for the idea of competitive federalism as a remedy for Germany's problems. "The logic of German federalism rests upon the notion of decentralised multi-level decision making. But rather than providing a national framework for a market-preserving federalism that enables sub-national units to compete with each other to find the most productive and democratically accepted innovative public policies, German cooperative federalism prescribes a complex web of interdependent decision-making that requires broad consensus both at the national and the state level in order to enact change' (Wiesenthal, 2003, 52). Germany's often lauded consensual and incremental policy style appears to have turned from a virtue into a vice. 
This points to another variable that is often omitted in studies on preference formation; namely, the important role played by ideas and processes of learning. Goldstein and Keohane (1993, 3) hold that ideas, understood as beliefs held by individuals, can influence policy when they can increase actors' clarity about goals, in situations where there is no unique equilibrium. In contrast to those who see ideas simply as 'hooks' to strategically propagate and legitimise interests, they regard ideas as playing an important causal role in preference formation. With the recent defeats of the SPD in key state elections, the red-green coalition has little chance of being able to enjoy a majority in the Bundesrat in the near future. With an increasing sense of political crisis alongside the economic one, pressure is increasing on the Social Democrats to adopt a policy of liberal reform, against its own traditional constituencies. This may explain the government's sudden enthusiasm to move from the current cooperative system to a more competitive federalism, in which states are free to engage in trial-and-error experimentation to find new ways out of the current political and economic deficiencies. Wiesenthal puts it thus: 'In this situation, the proposal to shift policy jurisdictions to the Länder, release them from the strictures of cooperative federalism and unleash policy experimentation and innovation at the sub-national level is gaining credibility. As long as path-breaking policy changes at the federal level are unlikely, granting individual states the right to greater policy-making autonomy might be a useful detour on the way to improved economic performance' (Wiesenthal, 2003, 56).

There are several indications that these reform attempts are being taken seriously. The recent Federalism Convention of the Länder and the November 2003 inauguration of a Federalism Commission made up of representatives of both houses of Parliament (with Edmund Stoiber as leader of the Länder) are concrete signs for this development. The declared aim of the Federalism Commission is to find ways to reallocate legislative competences between the Federal Government and the Länder and to re-design financial relations between the two levels of government (Frankfurter Allgemeine Zeitung, 16 September 2003). Some believe that this Commission could have a far-reaching remit. At its first meeting, the leader of the parliamentary Green Party, Beck even called for the creation of a Third German Republic to be legitimized by a popular referendum (Frankfurter Allgemeine Zeitung, 17 October 2003). There remain, however, widespread concerns that the existing institutional obstacles will make the adoption of any far-reaching changes to the current distribution of powers difficult to achieve and some worry that the Federalism Commission will end up as little more than a talking shop. Promoting competitive federalism through Europe might therefore have struck some German actors as the more promising avenue for reform. 


\section{Conclusion}

Germany's preferences regarding the kind of federal Europe it wants have been characterized by both continuity and change. On the one hand, on questions relating to institutional reform at the EU level, there has been considerable continuity in German preferences. Fischer's unwavering support for European integration, as well as Schröder's (rediscovered) commitment to the Franco-German partnership, do little to suggest that the current government has parted significantly from the aims of previous German governments. On the other hand, there has been a shift in Germany's preferences with respect to some other issues, notably, the vertical distribution of power in Europe. These preferences have at times been articulated with unprecedented bluntness. German demands for the renationalization of a number of policy areas and a clearer delineation of powers among the different levels of government, seem to suggest that, perhaps more than in the past, German preferences are guided by domestic considerations. Calls for the (partial) re-nationalization of the CAP and the Structural Funds, for the moment however, appear to be little more than a rhetoric bargaining chip as it is hard to imagine Germany ultimately supporting the anti-integrationist dynamic that such re-nationalization would trigger. Still, the German Länder appear to be more adamant than ever before that they want to keep Europe out of certain policy areas that they regard as their prerogative. Although they, like the government, have broadly welcomed the final text that was agreed on 18 June 2004, it is clear that at least for some of the those who had advocated a more rigid competence catalogue the provisions on 'categories of competences' in Title 3 of the Constitution are not going far enough. ${ }^{20}$

When analysing Germany's preferences regarding constitutional reform in Europe, close attention needs to be paid to the role of norms, interests and ideas. Germany's general preference for a federal structure for the EU appears to be at least in part norm-based, as Germans have come to believe in the inappropriateness of any centralized institutional solutions at home or in Europe. However, the competitive federalist model advocated more recently by Germany at the EU level, is more a reflection of strategic considerations by the German Länder and their dissatisfaction with Germany's own cooperative federalist model. Although the workability of a competitive federalist model for Europe as well as the extent and distribution of expected benefits remain uncertain, the concept of competitive federalism, has provided key German actors with an attractive alternative idea around which they could rally. Being sensitive to the role played by norms, interests and ideas in preference formation, can therefore help us better understand German preferences on the kind of European federation it wants. 


\section{Notes}

1 Chancellor Schröder has repeatedly referred to Germany as a 'great power in Europe', as a 'grown-up nation' with 'enlightened self-interests' (Schröder, 1999). Foreign Minister Fischer, has tried to balance this new rhetoric by repeatedly stressing that he sees it necessary to continue Germany's policy of self-restraint (Selbstbeschränkung) (see e.g. Fischer, 1993).

2 For a summary of Germany's position see the speech of German Secretary of State Pleuger at the Humboldt University on 26/10/2000, www.whi-berlin.de/pleuger.htm.

3 See the coalition agreement at: http://www.gruene-fraktion.de/rsvgn/rs_datei/0,,985,00.pdf, p. 78.

4 Letter to the Presidency of the Council, Berlin/London, 25 February 2002.

5 In his speech to the Belgium Parliament in 2000, Fischer even hinted at the possibility of directly electing the Commission President.

6 See joint Franco-German paper of 15/01/2003.

7 See also the German proposal submitted to the Convention's Working Group No. VII on 'External Action' of 5/11/2002.

8 Printed in: Blätter für deutsche und internationale Politik, Heft 5/2001.

9 Stoiber reiterated this threat after a meeting with Commissioner Barnier when he said that without a commitment to a clearer division of competences, Bavaria would vote against ratification of the Nice Treaty (Heute Aktuell, 14 April 2000) (http://www.dm-online.de/ euroaktuell/heuteaktuell/archiv_200004.html.) The reassurances given to the Länder in the Nice protocol on the Future of the Union led them to ratify the Nice Treaty on 9 November 2001.

10 One important difference between the positions of Clement and Schröder, however, is that the Chancellor insists that the division of power between the national and the subnational level should remain a question for the domestic politics of each Member State, while Clement appears to favour such a division as part of a wider European agreement on the distribution of powers in Europe.

11 Minutes of the 28th conference of the Europe ministers of the Länder.

12 Minutes of the 30th conference, 10-11/10/2001.

13 Bundesrat Drucksache 1081/01 of 20/12/2001.

14 In contrast to Belgium (see Bursens, this volume), the German government decided to nominate a regional representative to one of the two slots allocated to national parliaments at the Convention.

15 In the Convention, Germany was represented by three MEPs and two national parliamentarians. The three MEPs were former EP president Klaus Hänsch (PES), Elmar Brok (EPP) and Sylvia Kaufmann (EUL). As representatives of its Parliament, Germany sent Jürgen Meyer (SPD) and the Minister President of Baden Württemberg, Erwin Teufel (CDU) represented the Federal Council in the Convention. The German government initially was represented by a former parliamentarian and now full time academic Peter Glotz (SPD). In October 2002, he was replaced by Foreign Minister Fischer.

16 See also Knodt (2002) and Fischer (2003).

17 For an early analysis see Hrbek and Thaysen (1986).

18 See Stoiber (1987) or Stoiber's Humboldt speech on 8/11/2001: www.whi-berlin.de/stoiber.htm.

19 The highly controversial VW state aid dispute between the Commission and Saxony (Thielemann, 1999) is an excellent example of such frustrations.

20 The Bavarian government in particular, appears unhappy with parts of the Constitution. It had already distanced itself from the (largely positive) joint declaration of the Länder of June 2003 in which Länder gave their first political assessment of the Constitutional draft. See Bundesrat Drucksache $586 / 02$ of $23 / 07 / 2003$. 
21 2000a, www.whi-berlin.de/fischer.htm.

22 2000b, http://www.auswaertiges-amt.de/www/de/infoservice/download/pdf/reden/2000/r00111 4f.pdf.

\section{References}

Abromeit, H. (1992) Der verkappte Einheitsstaat, Opladen: Leske and Budrich.

Anderson, J. and Goodman, J. (1993) 'Mars or Minerva? A United Germany in a Post Cold War Europe', in R.E. Keohane, J.S. Nye and S. Hoffmann (eds.) After the Cold War: International Institutions and State Strategies in Europe 1989-1991, Cambridge: Harvard University Press, pp. 23-62.

Ash, T.G. (1993) In Europe's Name: Germany and the Divided Continent, New York: Random House.

Bulmer, S. (1997) 'Shaping the Rules? The Constitutive Politics of the European Union and German Power', in P.J. Katzenstein (ed.) Tamed Power: Germany in Europe, Ithaca: Cornell University Press, pp. 49-79.

Bulmer, S., Jeffery, C. and Paterson, W.E. (2000) Germany's European Diplomacy: Shaping the Regional Milieu, Manchester: Manchester University Press.

Checkel, J.T. (2001) 'Why comply? Social learning and European identity change', International Organization 55(3): 553-588.

Dehousse, R., Maurer, A., Nestor, J., Quermonne, J.-L. and Schild, J. (2003) The Institutional Architecture of the European Union: A Third Franco-German Way?, Notre Europe Working Paper No. 23, Paris: Notre Europe.

Fischer, J. (1993) 'Die Selbstbeschränkung der Macht muss fortbestehen', in K. Kaiser, (ed.) Die Zukunft der deutschen Aussenpolitik, Bonn: Europa Union Verlag, pp. 76-98.

Fischer, J. (1999) 'Speech to the European Parliament at the end of the German Council Presidency', Strasbourg, 21/07/1999.

Fischer, J. (2000a) 'Vom Staatenverbund zur Föderation — Gedanken über die Finalität der europäischen Integration', Available online.

Fischer, J. (2000b) 'Speech to the Belgian Parliament on 14/11/2000', Available online.

Fischer, T. (2003) 'Deutscher Föderalismus vor der Herausforderung einer europäischen Verfassung', Aus Politik und Zeitgeschichte B 29-30: 3-5.

Gerster, F. (1993) 'Die Europaminister-Konferenz der deutschen Länder: Aufgaben, Themen, Selbstverständnis', Integration 16(1): 61-67.

Goldstein, J. and Keohane, R.O. (1993) 'Ideas and Foreign Policy: An Analytical Framework', in J. Goldstein and R.O. Keohane, (eds.) Ideas and Foreign Policy: Beliefs, Institutions and Political Change, New York: Cornell University Press, pp. 3-30.

Harnisch, S. and Maull, H. (eds) (2001) Germany as a Civilian Power, Manchester: Manchester University Press.

Hesse, K. (1962) Der unitarische Bundesstaat,, Karlsruhe: Müller.

Hrbek, R. (2002) 'Deutscher Föderalismus als Hemmschuh für die europäische Integration?', in H. Schneider, M. Jopp and U. Schmalz (eds.) Eine neue deutsche Europapolitik?, Bonn: Europäische Schriften des Instituts für Europäische Politik, pp. 267-298.

Hrbek, R. (1999) 'The Effects of EU Integration on German Federalism', in C. Jeffery. (ed.) Recasting German Federalism: The Legacies of Unification, London: Pinter, pp. 217-233.

Hrbek, R. and Thaysen, U. (eds.) (1986) Die deutschen Länder und die Europäischen Gemeinschaften, Baden Baden: Nomos.

Hyde-Price, A. and Jeffery, C. (2001) 'Gerrmany in the EU: Constructing Normality', Journal of Common Market Studies 39(4): 689-717. 
Immergut, E.M. (1997) 'The Normative Roots of the New Institutionalism: Historical Institutionalism and Comparative Policy Studies', in A. Benz and W. Seibel (eds.) Theorieentwicklung in der Politikwissenschaft - eine Zwischenbilanz, Baden Baden: Nomos, pp. 325-355.

Katzenstein, P. (1997) 'Germany and Mitteleuropa', in P. Katzenstein (ed.) Mitteleuropa: Between Europe and Germany, Oxford: Berghahn.

Knodt, M. (2002) 'Europäisierung regionalen Regierens: Mit Sinatra zum 'autonomieorientierten Systemwechsel' im deutschen Bundesstaat', Politische Vierteljahreszeitschrift 43(2): 211-234.

Kreile, M. (2001) 'Das Schröder-Papier und die Jospin-Rede', Integration 24(3): 250-257.

March, J.G. and Olsen, J.P. (1984) 'The new institutionalism: organizational factors in political life', American Political Science Review 74 (3): 734-749.

March, J.G. and Olsen, J.P. (1989) Rediscovering Institutions: The Organizational Basis of Politics, New York: Free Press.

March, J.G. and Olsen, J.P. (1998) The Institutional Dynamics of International Political Orders, ARENA Working Paper 98/5, Oslo: ARENA/University of Oslo.

Marcussen, M., Risse, T., Engelmann-Martin, D., Knopf, H.J. and Roscher, K. (1999) 'Constructing Europe? The evolution of French, British and German Nation State identities', Journal of European Public Policy 6(4): 614-633.

Moravcsik, A. (1993) 'Preferences and power in the European community: a liberal intergovernmentalist approach', Journal of Common Market Studies 31(4): 473-524.

Moravcsik, A. (1997) 'Taking preferences seriously: a liberal theory of international politics', International Organisation 51(4): 513-553.

Moravcsik, A. (1998) The Choice For Europe, London: UCL Press.

Müller-Brandeck-Bocquet, G. (ed.). (2002) Deutsche Europapolitik von Konrad Adenauer bis Gerhard Schröder, Opladen: Leske + Budrich.

Scharpf, F.W. (1988) 'The joint-decision trap: lesson from German federalism and European integration', Public Administration 66(3): 239-278.

Schmidt, V.A. (1997) 'European integration and democracy: the differences among member states', Journal of European Public Policy 4(1): 128-145.

Schröder, G. (1999) 'Aussenpolitische Verantwortung Deutschlands in der Welt, Rede vom 2.9.1999 for dem DGAP', International Politik 54(10): 67-72.

Schröder, G. (2001) 'Verant wortung für Europa', Speech of 30/04/2001 to the SPD party conference. http://www.europa-digital.de/aktuell/dossier/reden/textschroeder.shtml.

Stoiber, E. (1987) 'Auswirkungen der Entwicklung Europas zur Rechtsgemeinschaft auf die Länder der Bundesrepublik Deutschland', Europa-Archiv 19(4): 543-552.

Thielemann, E.R. (1999) 'Institutional limits of a 'Europe with the regions': EC state-aid control meets German federalism', Journal of European Public Policy 6(3): 399-418.

Wiesenthal, H. (2003) 'German unification and 'model Germany': an adventure of institutional conservatism', West European Politics 26(4): 37-58. 